\title{
latrogenic Horner Syndrome: What is the Cause? Epidural Analgesia or Chest Tube? A Case Report
}

\author{
Hüseyin Utku Yıldırım $\odot$ \\ Şebnem Rumeli Atıcı ๑ \\ Gülçin Gazioğlu Türkyılmaz $\odot$ \\ Hadra Şafak Nebioğlu $\odot$ \\ Mesut Bakır (1)
}

\section{lyatrojenik Horner Sendromu: Etken Epidural Analjezi mi, Gögüs Tüpü mü? Olgu Sunumu}

\begin{abstract}
latrogenic Horner Syndrome (HS) may occur due to analgesia and surgical interventions. A case that developed HS following chest tube placement after lung surgery and opioid application via epidural catheter is presented here. The aim of this report is to discuss the differential diagnosis of HS in the light of the literature.
\end{abstract}

Keywords: Horner syndrome, chest tube, epidural catheter, opioid

öz

Anestezi ve cerrahi uygulamalara bağlı iyatrojenik Horner sendromu (HS) ortaya çıkabilmektedir. Göğüs cerrahisi sonrası göğüs tüpü yerleştirilen ve epidural kateterinden opioid uygulandıktan sonra HS gelişen bir olgu burada sunulmuştur. Bu makalenin amacı, HS'nin ayıııcı tanısını literatür ışığında tartışmaktır.

Anahtar kelimeler: Horner sendromu, gögüs tüpü, epidural kateter, opioid
Alındığı tarih: 09.05.2019

Kabul tarihi: 02.07.2019

Yayın tarihi: 26.07.2019

Atıf vermek için: Yıldırım HU, Rumeli Atıcı Ş, Gazioğlu Türkyılmaz G, Nebioğlu HŞ, Bakır M. latrogenic horner syndrome: What is the cause? Epidural analgesia or chest tube. A case report. JARSS 2019;27(3):228-31.

Şebnem Rumeli Atcı Mersin Üniversitesi Tıp Fakültesi, Algoloji Bilim Dalı, Mersin - Türkiye sebnematici@hotmail.com ORCiD: 0000-0002-7042-6934

H.U. Yıldırım 0000-0002-2438-4104 Antalya Șehir Eğitim ve Araștrrma Hastanesi, Algoloji bölümü, Antalya, Türkiye

G. Gazioğlu Türkylmaz 0000-0003-4148-1958 M. Bakır 0000-0002-3627-3882 Mersin Üniversitesi Tıp Fakültesi Algoloji Bilim Dalı, Mersin, Türkiye

H.Ş. Nebioğlu 0000-0001-6681-1576 Mersin Üniversitesi Tıp Fakültesi Göğüs Cerrahisi Anabilim Dalı, Mersin, Türkiye

\section{INTRODUCTION}

Horner syndrome (HS) manifests itself as ptosis, miosis and ipsilateral anhidrosis due to disruption of the oculosympathetic innervation pathway at any level which extend from hypothalamus to C8-T1 level and return to the eye (Figure 1). Ptosis of the upper lid and elevation of the lower lid cause enopthalmos (pseudoenopthalmos). Signs and symptoms may differ according to the level of affected pathway (central, preganglionic or postganlionic) ${ }^{(1)}$.
Epidural/spinal anesthesia, invasive procedures on neck region and apical lung surgery may lead to the development of preganglionic HS ${ }^{(2-5)}$. HS caused by chest tube (CT) placement was first reported in a premature infant ${ }^{(6)}$. Local anesthesics (LA) or LA-opioid combinations used in epidural anesthesia/ analgesia are reported to cause HS ${ }^{(7-9)}$. No report is available describing HS caused by solely opioid use during epidural analgesia. 
A case that developed HS following CT placement after lung surgery and opioid application via epidural catheter is presented here. The aim of this report is to discuss the differential diagnosis of HS in the light of the literature.

\section{CASE REPORT}

A 19-year-old male patient underwent video-assisted thoracoscopy (VATS) due to spontaneous pneumothorax developed in the right lung. Preoperatively, an epidural catheter was applied at L3-L4 level for postoperative analgesia. After resection of bullous structures in the lung, a CT was placed.

At the $12^{\text {th }}$ hour after the operation, the pain team was called to assess the patient's pain. The patient's visual analog scale (VAS) was 7. Morphine $(2 \mathrm{mg}$, in a total volume of $10 \mathrm{~mL}$ of $\mathrm{NaCl} 0.9 \%$ ) was administered via epidural catheter. After 30 minutes, the VAS score decreased to 1 . Two hours after administration of morphine, ptosis and miosis developed in the patient's right eye (Figure 2). The neurological examination was normal except for the ocular findings. The diagnosis HS was confirmed by an ophthalmologist.

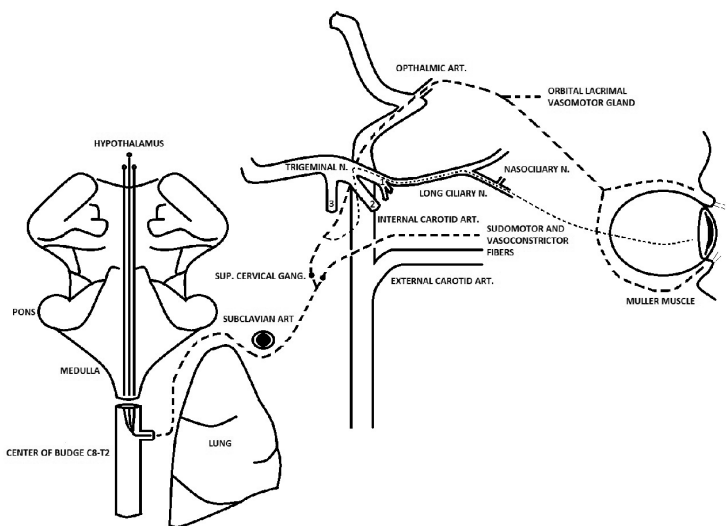

Figure 1. Anatomy of the sympathetic innervation of the eye ${ }^{(1)}$.

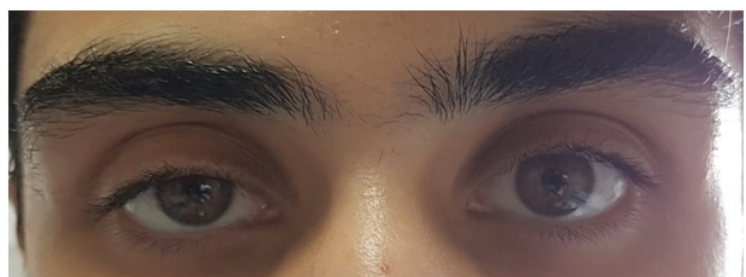

Figure 2. Miosis and ptosis at the right eye (Written informed consent was taken from the patient for this photo).
Chest X-ray revealed that the tip of CT was on apex of the right lung (Figure 3 ). The CT pulled backwards for $2 \mathrm{~cm}$ and significant decrease in miosis and ptosis was observed after 5 hours (Figure 4).

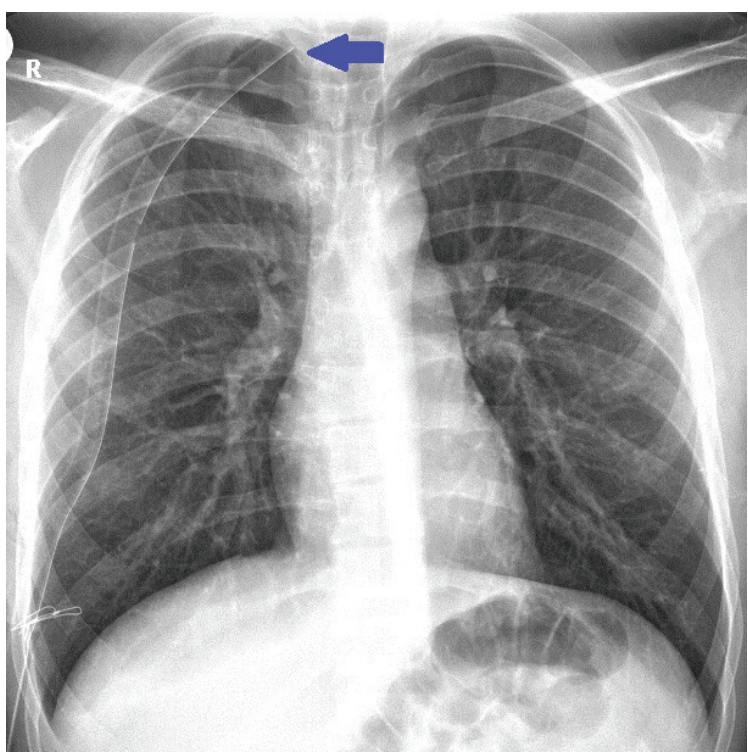

Figure 3. Chest- $X$ ray image of chest tube residing on the apex of the right lung (Black arrow shows tip of the chest tube).

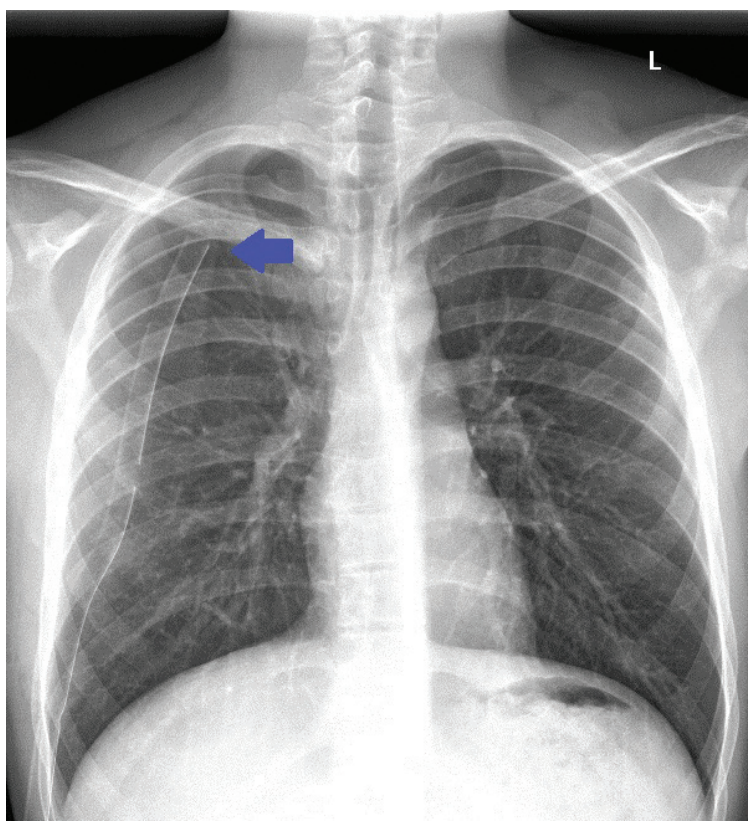

Figure 4. Chest-X ray image after chest tube reposition (Black arrow shows tip of the chest tube).

At the $18^{\text {th }}$ hour after the operation, the patient's visual analog scale (VAS) was 6 . Secondly, the same dose and volume of opioid was given via epidural catheter. Thirty minutes after administration the VAS 
score decreased to 2. HS symptoms were not observed.

On the postoperative $48^{\text {th }}$ hour epidural catheter was removed and the patient was discharged one week after the operation.

\section{DISCUSSION}

HS is not a life-threatening condition, but it may be a manifestation of central hypothalamus, central, spinal cord, head and neck pathologies. Therefore, it is important to make the differential diagnosis and determine the main cause ${ }^{(3)}$. In our case, both administration of drug through epidural catheter and CT were the reasons that may cause HS. The emergence of symptoms shortly after epidural administration of drugs suggested that the drug administered through epidural catheter might be responsible for the patient's symptoms. The main factor was considered to be the $C T$, because only opioids were delivered through epidural catheter. Regression of symptoms after repositioning of CT supports this view. It has been suggested that the administration of opioids through the epidural catheter increases the patient's mobilization by reducing pain, leading to displacement of the $\mathrm{CT}$, and harming lower cervical ganglion.

HS is a rare complication after epidural anesthesia $(10,11)$. It is thought that LA delivered through the epidural catheter moves upwards towards cranium and blocks the preganglionic fibers of the oculosympathetic pathway at the level of C8-T2. It is thought that the factors causing this spread may be related to variations in epidural anatomy and the patient's position. The development of HS after epidural anesthesia in the literature has been reported most frequently in pregnant women. In pregnant women, it is reported that epidural venous vessels are dilated due to increased intraabdominal pressure and LA rapidly spreads due to narrowing of the epidural space. This situation is considered to increase the risk of HS development in the pregnant women (12). In a study involving 439 mastectomized patients in whom thoracic epidural catheters were placed development of HS was detected in 6 patients $(1.4 \%)^{(12)}$. In this study, in a patient who demonstrated asymmetrical manifestations of HS on the right side of his face, when the contrast agent was given into the epidural space, the agent had spread to C5 on the right and T1 on the left. Development of unilateral HS is thought to be due to the variation of the septas in the epidural space ${ }^{(10)}$. Biousse et al. ${ }^{(11)}$ reported two patients with HS in whom epidural catheter was inserted in the lateral position and symptoms developed on the underlying side. They indicated that HS was lateralized on the side of the lateral decubitus during injection of the anesthetic solution was performed. In some of the HS case reports LA has been used in combination with opioid injection performed via epidural catheter. Any case of HS caused by the use of opioids was not encountered in the literature. In our case, the cause was not considered to be related to opioid use.

The proximity of the $\mathrm{CT}$ and the apex of the lung explain the development of HS with use of CT due to the trauma of the stellate ganglion. The reported incidence of HS after CT placement was less than $\% 0.5^{(13)}$. Zagrodnik ve Kline ${ }^{(5)}$ indicated that the stellate ganglion and the parietal pleura were separated by only a microscopically thin layer of loose connective tissue or endothoracic fascia. As a result of the movement of our patient, it was thought that the tube was displaced and traumatized the ganglion.

In patients with iatrogenic HS, the time to recovery or disappearance of symptoms varies. It has been reported in the literature that symptoms occur approximately one hour after epidural local anesthesia and spontaneously regressed approximately 2 hours after discontinuation of the drug administration ${ }^{(7,10)}$. In a study evaluating 78 cases of HS due to epidural anesthesia, only one case had persistent symptoms (7). According to the literature, the duration of pressure exerted by $\mathrm{CT}$ to the ganglia was reported to be important in the regression of the findings $(4,5,13,14)$. Many cases of HS due to CT were diagnosed between 12 hours and 12 days after surgery ${ }^{(5)}$. In a prospective study, the improvement of symptoms in 5 cases was reported between 2 weeks and 2 months after the procedure ${ }^{(13)}$. HS symptoms were detected in 42 days after a CT placement in a premature infant and the symptoms of this case were permanent ${ }^{(6)}$. In our case, symptoms developed 14 hours after the operation and regressed 5 hours after the replacement of the CT. Although the development process of HS in our case was similar to the literature, the 
time to recovery was very short. We thought that the immediate resolution of our patient's symptoms was due to rapid diagnosis of HS and rapid replacement of CT.

HS is not a life threatening condition but the persistance of the signs is a disruptive situation for the patient's life quality. Considering that the risk of development of HS will increase in cases where CT is placed and analgesia is provided with epidural drugs, it is important to follow up the symptoms at regular intervals.

Conflict of Interest: None

Funding: None

Informed Consent: Written informed consent form was obtained from the patient.

Çıkar Çatışması: Yoktur

Finansal Destek: Yoktur

Hasta Onamı: Olgudan yazılı onam alınmıştır.

\section{REFERENCES}

1. Glaser JS, Editor. Neuro-ophthalmology. $1^{\text {st }}$ ed. Hagerstown MD, USA: Harper \& Row; 1978, 133.

2. Knyazer B, Smolar J, Lazar I, et al. latrogenic Horner Syndrome: Etiology, Diagnosis and Outcomes. Isr Med Assoc J. 2017;19:34-8.

3. Korkmaz S, Hamamcıoğlu K, Öztürk $M$, Aksu $M$. Intratorasik Multinoduler Guatrın Neden Olduğu Horner Sendromu. Türk Nöroloji Dergisi. 2013;19:104-6. https://doi.org/10.4274/Tnd.39260

4. Bertino RE, Wesbey GE, Johnson RJ. Horner syndrome occurring as a complication of chest tube placement. Radiology, 1987;164:745. https://doi.org/10.1148/radiology.164.3.3615873

5. Zagrodnik DF, Kline AL. Horner's syndrome: a delayed complication after thoracostomy tube removal. Curr Surg. 2002;59:96-8. https://doi.org/10.1016/S0149-7944(01)00565-7

6. Rosegger H, Fritsch G. Horner's syndrome after treatment of tension pneumothorax with tube thoracostomy in a newborn infant. Eur J Pediatr. 1980;133:67. https://doi.org/10.1007/BF00444758

7. Chambers DJ, Bhatia K. Horner's syndrome following obstetric neuraxial blockade - a systematic review of the literature. Int J Obstet Anesth. 2018;35:75-87. https://doi.org/10.1016/j.ijoa.2018.03.005

8. Goel S, Burkat CN. Unusual case of persistent Horner's syndrome following epidural anaesthesia and caesarean section. Indian J Ophthalmol. 2011;59:389-91. https://doi.org/10.4103/0301-4738.83620

9. Hogagard JT, Djurhuus H. Two cases of reiterated Horner's syndrome after lumbar epidural block. Acta Anaesthesiol Scand. 2000;44:1021-3. https://doi.org/10.1034/j.1399-6576.2000.440822.x

10. Park SY, Chun HR, Kim MG, et al. Transient Horner's syndrome following thoracic epidural anesthesia for mastectomy: a prospective observational study. Can J Anesth. 2015;62:252-7 https://doi.org/10.1007/s12630-014-0284-9

11. Biousse V, Guevara RA, Newman NJ. Transient Horner's syndrome after lumbar epidural anesthesia. Neurology. 1998;51:1473-75. https://doi.org/10.1212/WNL.51.5.1473

12. Smith DI, Chiem JL, Burk S, Borovcanin ZC, Tran NH. Hemodynamic instability and Horner's syndrome following a labour lumbar neuraxial block: A warning sign of a potentially lethal event? J R Soc Med. 2017;110:245-8 https://doi.org/10.1177/0141076816681745

13. Kaya SO, Liman ST, Bir LS, Yuncu G, Erbay HR, Unsal S. Horner's syndrome as acomplication in thoracic surgical practice. Eur J Cardiothorac Surg. 2003;24:1025-8. https://doi.org/10.1016/j.ejcts.2003.09.014

14. Levy M, Newman-Toker D. Reversible chest tube horner syndrome. J Neuroophthalmol. 2008;28:212-3. https://doi.org/10.1097/WNO.0b013e318167552a 